ARTICLE

\title{
Understanding Public Sector Innovation from A Local Perspective: Contra War (Contraceptive for Women at Risk) Innovation Study in Malang Regency
}

\author{
Ali Roziqin and Amaliana Nur Fajrina \\ Department of Government Studies, Universitas Muhammadiyah Malang \\ Jl. Raya Tlogomas No.246, Malang, Indonesia
}

How to cite: Roziqin, Ali \& Fajrina, Amaliana Nur. (2021). Understanding Public Sector Innovation From a Local Perspective: Contra War (Contraceptive For Women At Risk) Innovation Study in Malang Regency. Jurnal Borneo Administrator, 17 (2), 205-222. https://doi.org/10.24258/jba.v17i2.803

\section{Article History \\ Received: 30 November 2020}

Accepted: 10 June 2021

Keywords:

Public Sector Innovation Contra War Local Government Malang Regency

\begin{abstract}
This research aims to understand public sector innovation from a local perspective with a study of the Contra War (Contraceptive for Women at Risk) innovation study in Malang Regency. This innovation aims to reduce maternal and infant mortality rates. This research used a qualitative study with document analysis. Researchers analysed documents from various sources such as official government reports, government regulations, online media news, scientific literature, and books. The result shows that the Contra War innovation has not significantly reduced maternal and infant mortality, but gradually the Contra War has reduced maternal mortality index (Angka Kematian Ibu/AKI) cases from 27 in 2019 to 14 cases. Meanwhile, infant mortality rate (Angka Kematian Bayi/AKB as many as 62 people in 2020. Another side, the sustainability of innovation has not gone well because of low participation, innovative organisational capacity, and transformational leadership. Therefore, researchers provide suggestions for increasing public participation, collaborating with third parties, and creating innovative work ecosystems and bureaucratic structures.
\end{abstract}

\section{A. INTRODUCTION}

Traditionally the study of government science has been adapted specifically to explain public sector innovation (Boehmke \& Witmer, 2004:39). The public sector in question consists of services such as education, health, and other public affairs (Arundel et al., 2019:789). In general, innovations carried out by the public sector focus on governance and policies needed as a means to solve social problems. Moreover, looking at the complexity of problems in the modern era that must be solved with more innovative and adaptive solutions following the development of dynamics in society (Torfing \& Ansell, 2017:1; Demircioglu, 2019:217).

Why innovation? Because if only with regular policy, the problem is difficult to solve. Besides, innovation has been shown to increase the capacity of public organisations, public services, and responsiveness to the demands of society (Bekkers, V. et al., 2011:6; Dorsman et al., 2014:1; Torfing \& Ansell, 2017:14). We give examples of innovations on policy types, according to the OECD (Organisation for Economic Cooperation and Development)

\footnotetext{
* Corresponding Author

Email: aliroziqin@umm.ac.id
} 
explaining, that policy innovation aims to help incrementally change development, development of a broader system of change, multiply the actions of policy agencies both by input, coordination, and implementation (Grillitsch et al., 2019: 1048; OECD, 2015). Policy innovation is part of the government's drive to increase trust and satisfaction with the government bureaucracy (Anggraeny, 2013:85-86; Murtadho \& Roziqin, 2018:111). Innovation is a demand for both central and regional public organisations (Sururi, 2017: 15) because policy innovation is not limited to certain areas only, but entirely (McGann et al., 2018:250), including in the field of health.

This article focuses more on public sector innovation, especially in solving local social problems in health. The health sector is part of the basic services received by the community from the service provider (government). According to the Law of the Republic of Indonesia No. 36 of 2009 on health states that health development should be aimed at raising awareness, willingness, and ability to live the community as high as. This is an investment for the development of community resources (Putra, Usman, \& Abdi, 2017: 295) because the community has high hopes for changes in preferences and quality of public sector services, and that can be realised, one of which is public sector innovation (Dorsman et al., 2014:1).

Speaking of maternal and infant mortality, Indonesia is one of the countries with a high number. In particular, the maternal mortality rate reached 305 per 100,000 live births in 2019 (Susiana, 2019:13). This issue is not only happening in Indonesia but also a global issue and has been stated in one of the goals of Sustainable Development Goal's (SDGs), which is to improve maternal health. Maternal and infant mortality is an issue that needs attention for the government as a policymaker (Rene et al., 2019:335). Through the public sector, innovation is expected to provide revolutionary improvements in the community (Maranto \& Wolf, 2013:236; Lapuente \& Suzuki, 2020:1). That is in line with the study of public sector innovation that is increasingly getting attention from practitioners and academics in Indonesia (Pratama, 2019:25).

This research takes an innovative study about Contra War (Contraceptive War). This innovation is an effort to accelerate the decline in Maternal and Infant Mortality (Angka Kematian Ibu/AKI-Angka Kematian Bayi/AKB) in Malang Regency. Previously, the maternal mortality rate in Malang was still quite high. In 2016, there were 21 deaths, while in 2017, there were 18 deaths. Furthermore, 2018 showed the number of maternal deaths in Malang district of 17 cases. Next, in 2019, the mortality rate of pregnant women increased to 28 (Sigit, 2020). So it is not surprising that in 2017 Malang regency is still included in the top 10 cities/districts with the highest maternal mortality rate in East Java (Muhammad, 2020). The infant mortality rate in Malang regency is also quite high. According to the report of accountability of Malang Regency in 2018, the infant mortality rate in 2017 amounted to 1.61 per thousand inhabitants. Then in 2018 , it increased to 2.08 per thousand inhabitants.

\section{B. LITERATURE REVIEW \\ Public Sector Innovation: A Local Practice}

Public sector organisations such as governments need to innovate for a variety of reasons, such as community demands, the complexity of problems, and improvements to public services (Arundel et al., 2019:793). In recent decades, there have been many articles discussing public sector innovation from a wide variety of perspectives (Bekkers \& Tummers, 2018:210; Janssen et al., 2017:190). The increasing study of public sector innovation among academics and government practitioners (Demircioglu, 2019a; De Vries et al., 2016:146) is inseparable from the emergence of the New Public Management concept. It has implications on the discourse on public sector innovation that is spreading in many countries (McGann et al., 2018:251). Some countries in the Asia-Pacific region also face similar challenges related to the topic of public sector innovation (van der Wal \& 
Demircioglu, 2020:3), not least developing countries such as Indonesia, which make it a political agenda and government administration (Pratama, 2019:25).

Radically, innovation is defined as a product that is used to break the old ways (Bekkers \& Tummers, 2018:210) and reduce costs (Borins, 2018:1860). Whereas according to Cinar et al., (2019:2), innovation is a new idea created, developed, and recreated for the adopted from new units. According to Pratama (2019:27) and Kusumasari et al. (2019:432), to understand public sector innovation, the first thing to know is innovation. The study of innovation was inseparable from Schumpeter's contribution in the late 1920s, which emphasised that the renewal of innovation lies in the resulting outcome. Furthermore, Schumpeter in Pratama (2019:27) defines innovation as a commercial application of new technologies, new materials, and new methods in the advancement of the industry. At the same time, innovation in public organisations such as government emphasises the value of publicity itself (Goodsell, 2017:471).

Public sector innovation is a new idea or practice developed by public organisations to improve the quality and effectiveness of services to the community (Bekkers \& Tummers, 2018:210; Borins, 2014:6; De Vries et al., 2016:152; Demircioglu, 2019:217; Janssen et al., 2017:189; van der wal \& Demircioglu, 2020:2). The main focus of public sector innovation is the analysis of individuals and organisations by assessing why and how it is implemented (Demircioglu, 2019:217). Also, public sector innovation aims to increase the capacity of human resources (Borins, 2018:1861) and solve various social challenges (Arundel et al., 2019:1-3; Torfing \&Ansell, 2017:790).

Today, public sector innovation is a popular topic for government studies scientists (van der Wal \& Demircioglu, 2020:2). Bekkers \& Tummers (2018:210) explains that innovation is different from improvement efforts. There are four main differentiators, including: innovation process, Service products or innovations, governance innovation, conceptualisation of innovation

Although previously De Vries et al. (2016:153) have divided the types of public sector innovation into several types as described in Table 1.

Table 1. Type and Focus of Innovation

\begin{tabular}{ll}
\hline Innovation Type & Focus \\
\hline Innovation process & $\begin{array}{l}\text { Improving the quality and efficiency of internal and external } \\
\text { processes } \\
\text { Create a new organisational format form including management } \\
\text { Innovation of administrative process }\end{array}$ \\
$\begin{array}{ll}\text { Innovation of technological process } \\
\text { Create or use new technologies to provide services to users and } \\
\text { communities }\end{array}$ \\
$\begin{array}{l}\text { Innovation of products or service } \\
\text { Innovation of governance }\end{array}$ & $\begin{array}{l}\text { Develop new forms and processes to address social problems } \\
\text { The introduction of a new concept, a new paradigm that might be } \\
\text { Innovation of conceptual }\end{array}$ \\
\hline a solution
\end{tabular}

Source: Adopted from De Vries et al. (2016:153)

The majority of public sector innovations in Indonesia emphasise more on the aspects of information technology and administrative and casuistic changes (Pratama, 2019:26), the development of new or existing programs to be more effective (Andhika, 2018a:153).

Public sector innovation in local government aims to improve government relations with the public (Häikiö, 2012:415). De Vries et al. (2016:154) explained that the purpose of public sector innovation, in general, is to increase effectiveness and efficiency, solutions to social problems, community satisfaction, community participation, and private cooperation. Strategically, government intervention and structured innovation efforts are key to solving 
public problems (Hjelmar, 2019:5), as evidenced by the practice of public sector innovation in countries such as the United Kingdom and Italy in offering this type of benefit service to the public (Sinni, 2017:53368). Even in other studies followed by the emergence of the public sector innovation laboratory (McGann et al., 2018:250).

Innovations formed by the government must also be committed to results and sustainability (Osborne, 2009:4). There are at least three stages to make it happen, namely: commitment and adherence to performance, results-oriented system, integrating politics and administration

If all three things can be applied properly, innovation in local government can continue without being affected by the leader. Also, public sector innovation in government must be institutionalised formally and culturally, as Hjelmar (2019) explains, the public sector innovation experience in Denmark.

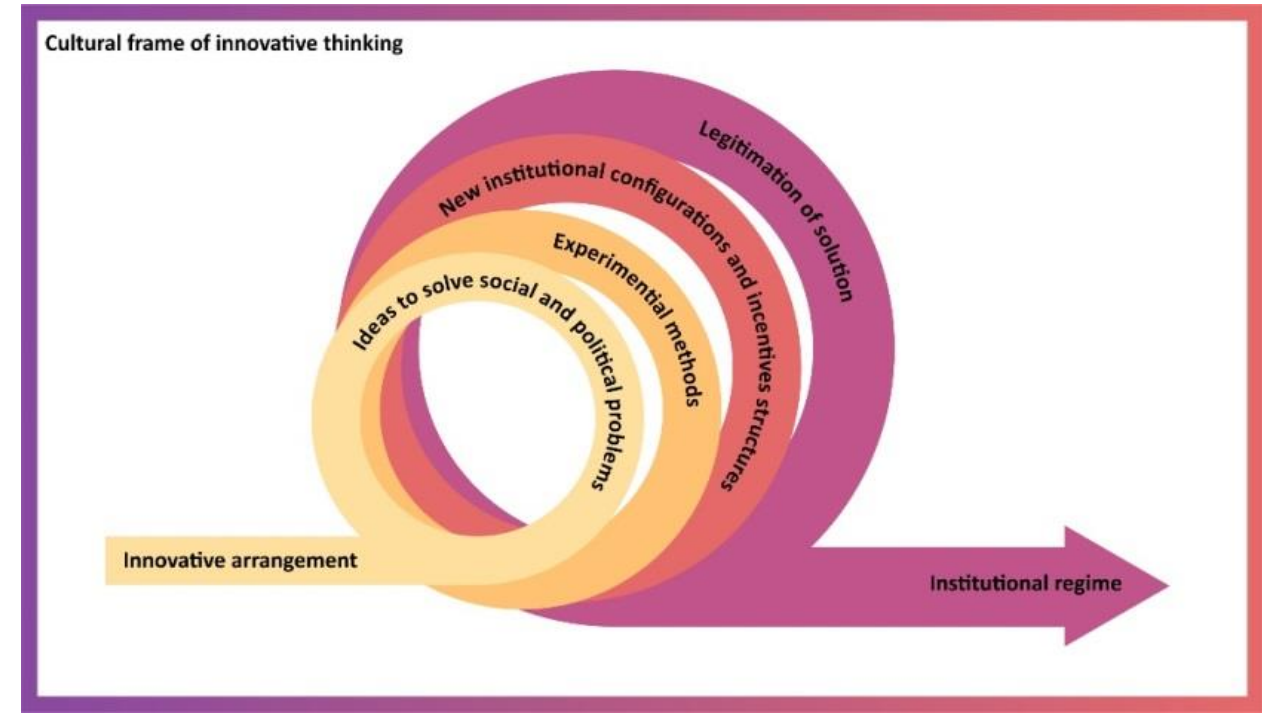

Source: Adopted from Hjelmar (2019:5)

Figure. 1. Innovative Arrangement

Figure 1 shows that to put together an innovative public organisation, creative ideas are required through several experiments. After being tested, a new institutional configuration and incentive structure were established, and the latter legally became a well-institutionalised solutive step.

Lessons from Canada explain that public sector innovation is influenced by environmental variables such as economic strength, quantity and quality of the apparatus, investment in research and development, and type of government (Bernier et al., 2015:842). At the same time, public sector innovation in local government is more determined by internal factors than external (Walker, 2014:23), such as organisational size, organisational capacity, and learning organisation. Meanwhile, De Vries et al. (2016:155) explains that four main factors influence public sector innovation first is environmental factors; organisational factors; The three factors of innovation; and The four individual factors that include the capacity and knowledge of the employees. Almost the same opinion was presented by Demircioglu \& Audretsch (2017:1682) that public sector innovation is determined by organisational size, location, performance, and investment in human capital.

Furthermore, innovation can have a wider impact due to strong political leadership through collaboration (Torfing \& Ansell, 2017:1-3) and developments and changes in the modern era that make technology Internet of Thing to make it more "smart" (Velsberg et al., 2020:1). Furthermore, the explanation of Arundel et al. (2019:790) says that to measure how 
innovation happens and the process, there are at least a few things to note, such as innovation strategy management, innovation management, innovation culture, and the capabilities of managers or leaders in supporting innovation. However, some of the explanations above show that, in general, matters affecting public sector innovation are contextual (Demircioglu \& Audretsch, 2018:824). While the emphasis on local government perspectives cannot be separated from the assumption that they have a great responsibility to the public services used daily (Walker, 2014:22)

Previous research on public sector innovation in Indonesia has been conducted in many fields, especially in the field of health. Such as innovation based on home care in Makassar City (Putra et al., 2017:294), and innovation of health care Puskesmas (Public Health Center) in Surabaya (Anggraeny, 2013:85). Meanwhile, Pratama (2019:25-26) explained that public sector innovation in Indonesia in the period 2014-2016 is dominated by local governments with innovation characteristics that combine administrative and technological dimensions.

From a local perspective, the principle of regional autonomy has implications for the emergence of innovations by the local government (Febrian, 2018:46; Pratama, 2019:26; Borins, 2014:11). Public sector innovation also occurs at the village level to help data management and information disclosure for the villagers (Eprilianto, Pradana, \& Sari, 2019). However, from some previous studies, there is still limited research that explains the identification of public sector innovations in solving social health problems (Andhika, 2018b:19). Therefore, some of the above research has inspired the author to review the problem of public sector innovation Contra War in Malang Regency. In its explanation, the authors used a framework of previous research in analysing the phenomena found. The author demonstrates the phenomenon of problems with two main points, first innovation and efforts to solve social health problems. Second, examine in an innovative and institutional setting. This article is expected to contribute knowledge to public sector innovation studies, as well as provide information to practitioners to successfully develop impactful and sustainable public sector innovations.

\section{METHOD}

This research is a framework based on qualitative research. According to Goodman (2011:9), the design of qualitative research aims to assist researchers in understanding the social and cultural context of the communities in which they live. Based on the phenomenon of research on health and social issues, this study also falls into the category of health research with the approach document analysis (Conrad, 2001:6610). According to Kayesa \& Shung-King (2021:2), document analysis is a method of collecting research data with various documents, both printed and electronic, to interpret a certain topic to answer research questions. Previously, this type of document analysis data collection has been widely done in health policy analysis (Kayesa \&Shung-King, 2021:1)

Researchers analyse documents from various sources such as government white papers, government regulations, news in online media, scientific literature, and books. The documents were used as central data by researchers in discussing the phenomenon of Contra War innovation in the Malang Regency. Especially for the use of scientific literature, researchers use the following strategies to regurgitate the bias of the documents used. 
Search criteria in google scholar "innovation" and "Public Sector Innovation"

196.000 documents

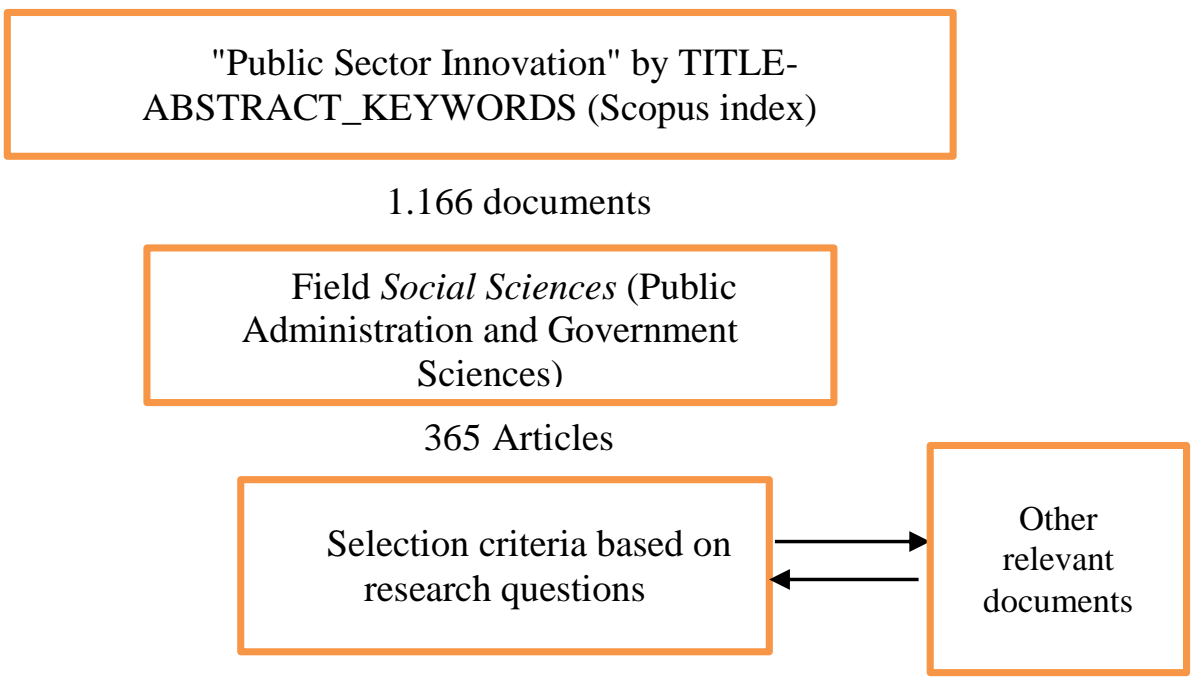

50 Scientific article documents

Figure. 2. Selection of Criteria of Scientific Literature Documents

Based on figure 2, the researchers first used the keyword "innovation" in google scholar. Then, because the main theme in this study is public sector innovation, researchers searched with the search words innovation and public sector innovation published from the range between 2000 to 2020 in google scholar (as of September 18, 2020). There are about 196,000 documents, be it articles, proceedings, patents, and digital books. Meanwhile, to maintain the quality of the paper that is used as a reference, researchers narrowed the search public sector innovation as keywords in Scopus indexation by title, abstract, and keywords (TITLE-ABS-KEYWORDS). As a result, there are 1.166 documents published in various journals and publishers. Then, for the field of social sciences, there are 365 scientific articles.

To minimise bias, researchers used only articles that discuss public sector innovation within the framework of public administration and governance. In total, 50 journal articles become references, both the lowest indexed google scholar to indexed WOS (Web of Science) and Scopus. Besides, there is also a national journal accredited SINTA (national accreditation of Indonesian journals) that becomes a reference for writing. The reference journal article is the result of the journal blind review.

The choice of the Contra War innovation as the object of this research is because this innovation has received awards and the fact that the Maternal and Infant Mortality Rate (MMR) is still high. Besides that, the selection of studies conducted on Contra War innovations in Malang Regency is in line with what was conveyed by Bernier et al. (2015:836) that, in general, innovation studies are based on case studies in one particular place.

\section{RESULT AND DISCUSSION Local Innovations and Problems}

The evolving dynamics of society and complex local government order require local government to make gradual changes (Ammons et al., 2012:645). It is especially considering that the role of local governments is more intense in providing direct public services. It is 
inseparable from the process of diffusion and locality of public sector innovation as a strategy to improve performance, efficiency, and public value (Hartley \&Rashman, 2018: 2; Hartley, 2005:27). Also, the development of information technology is increasingly advanced, requiring local governments to utilise information technology in support of government tasks and policy making (Janssen et al., 2017:190). It was supported by Rozikin et al. (2020:63), which explained that innovative products in the region can help the implementation of egovernment, especially Indonesia, which has always been identical in innovation studies, and e-government as two important entities in the perspective of the public sector innovation. Moreover, it was found that inter-regional facts have different characteristics of problems (Walker, 2014:39). The innovations that are born need to understand the wisdom and real problems at the local level. The increasing study and practice of innovation in local governments seem to want to eliminate innovation studies that have been attached to the private sector (Nählinder, 2013:317).

Innovation activities in a public organisation can not be separated from the influence of individual motivations, organisational culture, and challenges for the apparatus (Demircioglu \& Audretsch, 2017:1682). However, if we look at the cultural conditions of bureaucracy and resources in the region, it is difficult to make innovative efforts. Moreover, our bureaucracy is known to be rigid, complex, and political (Mubin \& Roziqin, 2018: 241; Niskanen, 2012: 98). In the public sector innovation process, there are at least three things that need to be known; First, who are the actors who are actively involved; Second, what types of activities contribute to innovation; Third, the knowledge or technology-based innovation mode (Diercks et al., 2019:882). Public sector innovation is an important agenda in government bureaucracy to help solve the problem of development (Demircioglu, 2019:219) and become a breakout force for economic growth and public welfare (Demircioglu \& Audretsch, 2018:820).

Health problems, especially for mothers and babies, have become a special concern for the government of Malang Regency, to reduce the problem of high maternal and infant mortality, contra war innovation that refers to the Decision of the Regent of Malang No. 188.45/594/421.013/2014 concerning the establishment of a control team for contraceptive programs for women of high-risk childbearing age (Contraceptive for Woman at Risk). This innovation emphasises the reference of data as a reference in handling cases to be handled faster because the data used in real-time, based on name, address, and case. Also, the data presents couples of childbearing age who are at risk in real-time. This program then developed further into the program E-Family, which integrates various data sources in realtime and monitored through the technology Command Center in hopes of making it easier to monitor population data in Malang. Some of the available data include the population by age category, the number of pregnant women and newborns, the number of couples of childbearing age who have not used family planning, as well as the number of maternal and infant deaths during childbirth, and this innovation process is said to be evidence-based innovation.

Contra War's innovation is an effort to combine active community participation and technological advancement through the provision of valid and integrated data. Contra War innovations began to be actively implemented to reduce maternal and infant mortality in 2016. The high number of maternal and infant mortality cases in Malang Regency is caused by many factors (see table 2). Most of the infant mortality rates are cases of LBW (Low Birth Weight Babies) born to mothers with poor pregnancy quality. So if most of these cases can be identified early, then the assumption to lower the case of Maternal and Infant Mortality (AKB-AKI) is greater chances. 
Table 2. Problems and Causes of Maternal and Infant Death in Malang Regency

Cause of Problem

1. Women of childbearing age and high risk have not had birth control.

2. Women who are fertile and at high risk have not received good birth control.

3. Childbirth without competent health workers.

4. Health workers no practice license.

5. Lack of health facilities.

6. Hospitals Referral is needed long bureaucratic chains.

7. There are no standard guidelines in birth control services for women of childbearing age and high risk.

\section{Root Cause (Leverage)}

1. There are no guidelines that are used to find, report, and intervene early (mitigation) for groups of women of childbearing age and high risk who need family planning services but have not been served (unmeet need).

2. The inadequate regional health system

3. No community-based surveillance has been conducted for wus (Women of Childbearing Age) at high risk, pregnant women at high risk, and high-risk babies

4. The absence of integrated handling from the Population Control and Family Planning Agency

Source: Population Control and Family Planning Agency /Dinas Pengendalian Penduduk dan Keluarga Berencana, (2018)

The table generally explains that the main subjects of the problem of high cases of maternal and infant mortality are community participation and the capacity of health facilities owned by Malang Regency In 2019, the population of Malang district reached 2,935,138 people (BPS Malang Regency, 2020) and productive age (15-64 years) with presentations reaching 68.12\%. In addition, Malang Regency, as the second-largest regency in East Java with an area of $3,530.65 \mathrm{~km}^{2}$, also resulted in the non-concentrated community residence in one place, so that this affects the accessibility of the community and existing health facilities.

Graph 1. Health Facilities in Malang Regency

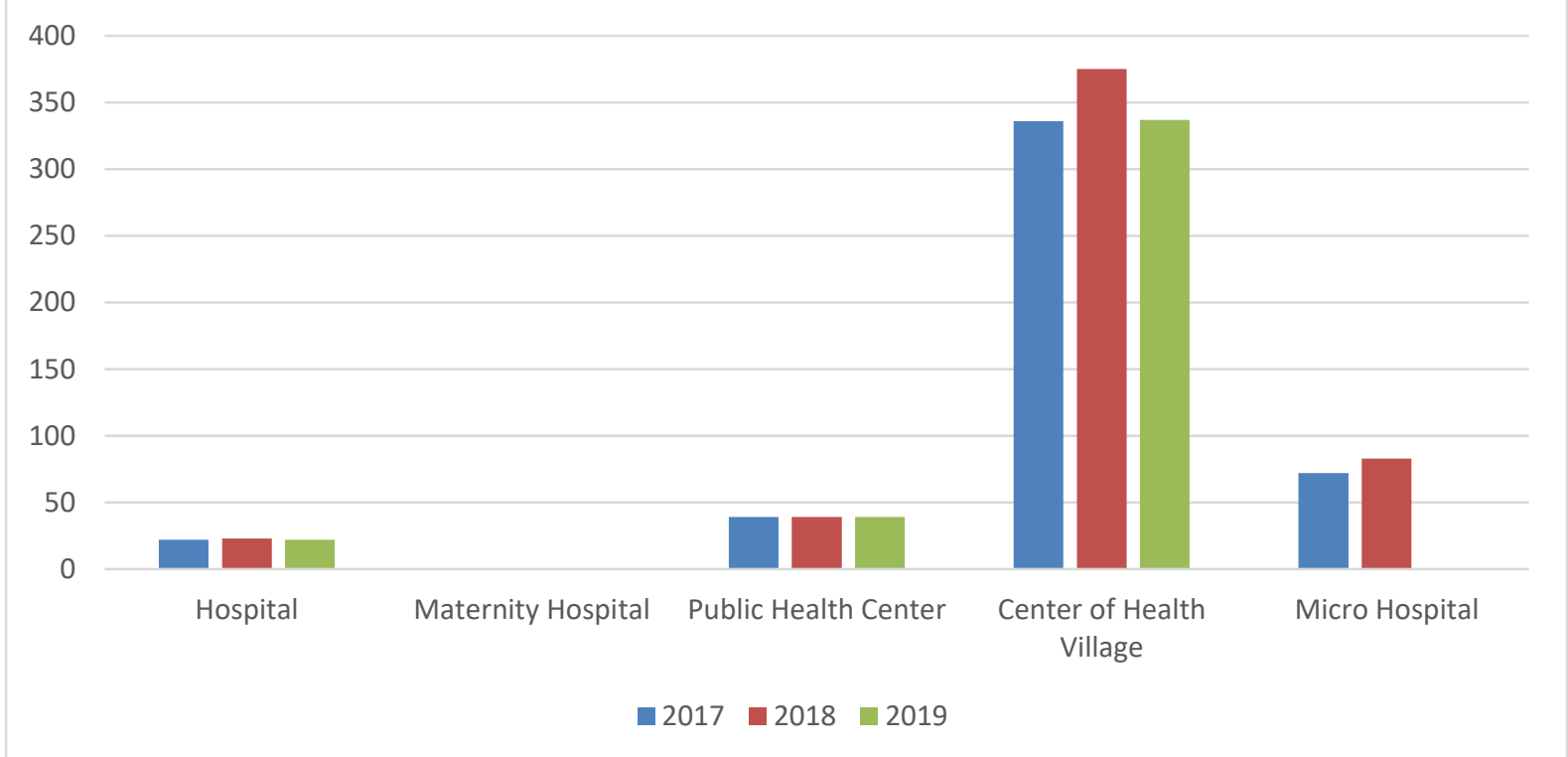

Source: BPS Malang, 2020

Judging from figure 2 in 2019, Malang Regency has 22 hospitals, then 39 health centres, and 337 village polyclinics. While the number of Posyandu in 2019 reached 2842 and decreased from the previous figure of 2872 in 2018. Posyandu is the most popular health facility in the district community.

Contra War's innovation target group is women of childbearing age who have been married, have not joined $\mathrm{kb}$, and are not pregnant, whether they are suffering from illness or 
Understanding Public Sector Innovation From a Local Perspective: Contra War (Contraceptive for Women at Risk) Innovation Study in Malang Regency

undergoing certain treatments. Of the many women of childbearing age, 384 use birth control. 628 (see table.3).

Table 3. Number of Couples of Childbearing Age malang Regency and KB Type 2018

\begin{tabular}{|c|c|c|c|c|c|c|c|c|}
\hline \multirow{2}{*}{$\begin{array}{c}\text { Number of } \\
\text { Couples of } \\
\text { Childbearing } \\
\text { Age }\end{array}$} & \multicolumn{7}{|c|}{ KB Types } & \multirow[t]{2}{*}{ Total } \\
\hline & IUD & MOWI & MOP & CONDOMS & Implant & Injections & Pills & \\
\hline 508.649 & 56.682 & 18.942 & 503 & 3.534 & 49.830 & 194.985 & 60.152 & $\begin{array}{l}384 . \\
628\end{array}$ \\
\hline
\end{tabular}

Source: BPS East Java Province (2019)

Meanwhile, in the same year, 2018, women of childbearing age (15-49) who received kb counselling amounted to 44.404 people (Malang, 2018). This means that there are still many target groups that are not well served (Unmet Need).

The innovation of Contraceptive for Women at Risk in Malang Regency is intended to reduce Unmeet Need, maternal mortality, and infant mortality. By combining several approaches, Contra War's innovations have the following flow:

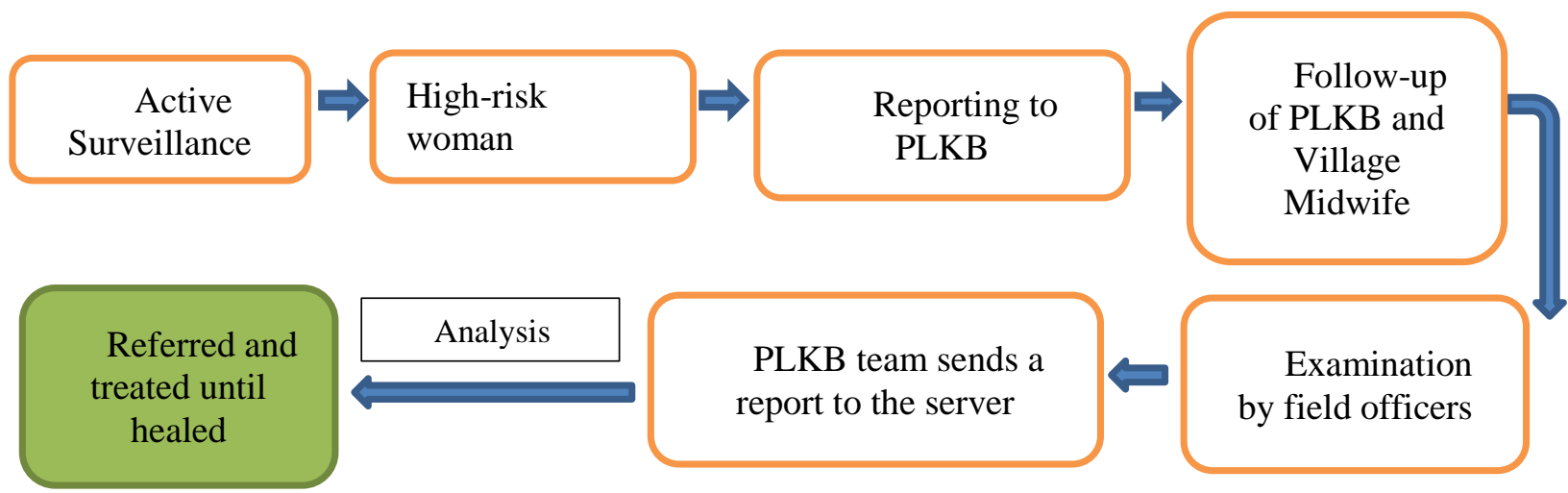

Source: Population Control and Family Planning Agency /Dinas Pengendalian Penduduk dan Keluarga Berencana, (2018)

Figure. 3. Contra War Service Process Flow

Based on the flow, the important roles that become the starting point are the cadres consisting of PPKBD (Village KB Assistant Coach), Sub PPKBD (Village KB Assistant Coach at RW level), and Posyandu Cadre. They do surveillants, data collection, systematic data analysis that is reported to the server through android-based gadgets. The activeness of cadres in conducting surveillance plays a major role in the provision of data and rapid response of treatment to women of childbearing age who are at high risk. Contra War's innovation process is, as described by Walker (2014:22), the focus of how the service is delivered. This innovation in the data collection process also has an impact on changing organisational communication patterns and making supervision more flexible.

Conceptually, the flow emphasises the participatory efforts of cadres and the community so that the active participation patterned bottom up has a considerable determinant in the success of innovation. As explained by Haikio (2012:415) that community participation can be done in various ways in local government governance. This was supported by Bakici et al. (2013:320) in his study in several local governments such as Finland, Germany, the Netherlands, and Spain, which showed that innovation in local governments requires direct 
participation from the community. At the same point, innovation in the Australian government also runs on a bottom-up (Demircioglu, 2019:223). Next also in Africa (Biljohn \& Lues, 2020:229). The bottoms up process in public sector innovation to be a solution that can raise collective awareness and attention to engage in solving social problems.

\section{Innovative And Institutional Local Order}

Many studies on public sector innovation focus on individual and organisational levels, without examining why innovation occurs in certain public organisations, and or leaders and staff are more innovative than others (Demircioglu, 2019:217). In local government studies, organisational capacity such as administrative intensity, manager, finance, personnel is an important tool related to innovation (Walker, 2014:26).

The implementation of Contra War innovation involves several stakeholders, consisting of: (1) Regent of Malang, as a mentor and coach for the smooth innovation of Contra War in Malang Regency; (2) Regional Secretary, as the person in charge of implementing the Contra War program; (3) Administrative Assistant of Government and Legal Department, as an institution for the preparation of contra war innovation law/regulation products; (4) Dinkes, RSUD, KP3A as SKPD technical implementation partner of Contra War innovation; (5) DPPKB, especially Kader $\mathrm{KB}$, is the spearhead of implementing to obtain data related to couples of high-risk childbearing age and other causes of disease to be reported to PLKB/PKB/Midwife Village; (6) Puskesmas (Public Health Center) as a provider of contraceptives as well as providing services to handle the initial action of healing the disease, if not handled, then referred to the hospital.

With the institutional pattern mentioned above, communication between stakeholders under the roles of their respective functions can be realised. Contra War innovation includes a variety of human resources consisting of: PPLKB 98 Persons; Village Midwife 728 People; PPKBD 390 People; Sub PPKBD 3.441 People; Posyandu Cadre 25.000 People supported by IT facilities facilitated by the Office of Informatics and Communication of the Malang Regency Government.

Contra War innovation is technically under direct control by the Population Control and Family Planning Agency Malang Regency. In practices, it is also supported by PPKBD, Sub PPKBD, Cadre in Posyandu; PLKB/PKB, Village Midwife; and contra war server operators. During 2019, Contra War innovation financing was included in the population control data program and family planning service program, with the following details:

Table 4. Budget allocation and realisation

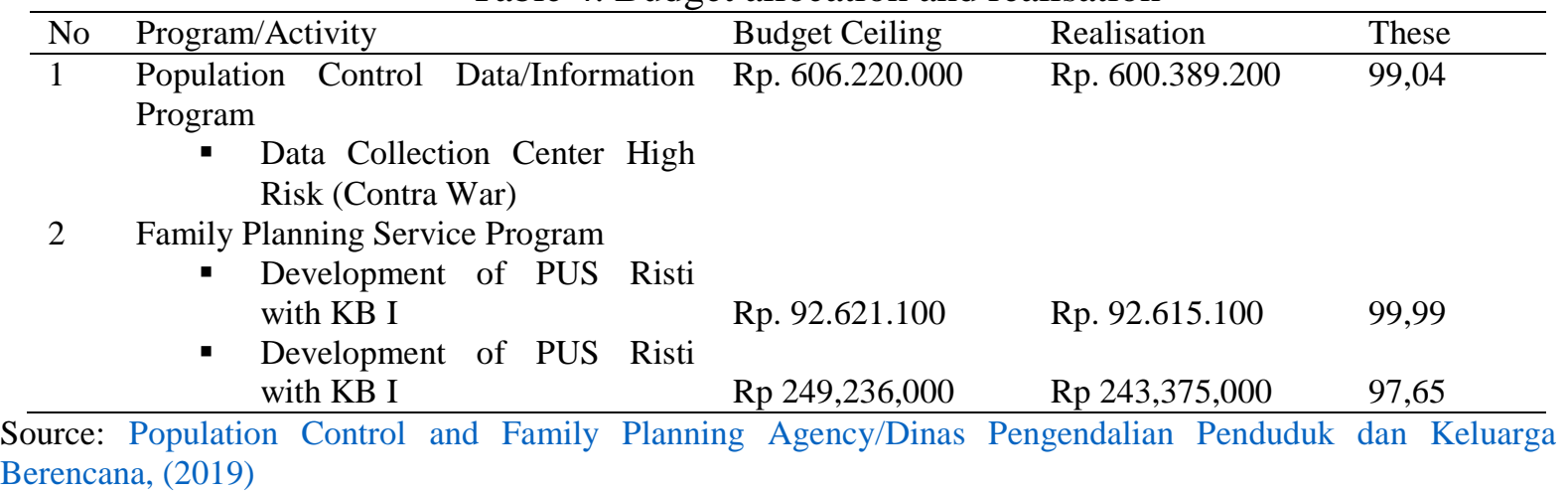

High Risk PUS (Couples of Childbearing Age) development activities served by KB have been served by 3,513 people. Meanwhile, financing from the Special Allocation Fund reached $97.65 \%$. The achievements of the Contra War program are indeed quite high. But there is no guarantee that maternal and infant mortality rates are significantly decreased. That 
Understanding Public Sector Innovation From a Local Perspective: Contra War (Contraceptive for Women at Risk) Innovation Study in Malang Regency

is because there are some internal obstacles in the field, such as mindset, fighting patterns, and must have the soul of the entrepreneur to support counselling.

Contra War innovation also has several approaches to achieving goals, which are described in table 5 .

Table 5. Contra War Innovation Approach

\begin{tabular}{ll}
\hline Approach Type & Subject \\
\hline Organisational approach & - Malang Regency Health Office \\
& - Regional Public Hospital \\
& - $\quad$ Assistant for People's Welfare \\
& - $\quad$ Pappeda \\
Participation approach & - Sub PPKBD (Village Kb Development \\
& - $\begin{array}{l}\text { Pssistant at RW level) } \\
\text { Information technology-based approach }\end{array}$ \\
& Supported by a database connected to field \\
& officers consisting of PPLKB and Village \\
& Midwife and they can send to data computer \\
& server (Contra War) \\
\hline
\end{tabular}

Source: Population Control and Family Planning Agency /Dinas Pengendalian Penduduk dan Keluarga Berencana, (2018)

From the above approach, it is expected that the process of speed and accuracy in detecting early and handling $\mathrm{kb}$ services can be realised. In addition, the availability of surveillance data and contraception in Puskesmas (Public Health Center) can help prevent the occurrence of pregnancy with a high risk. Because of what is felt by the community so far, the handling of the family planning program is relatively general, and there has been no special attention, so it has an impact on the number of unmet needs, MMR and IMR, which are still high.

The result of contra war innovation mechanism is gradually able to reduce maternal mortality and infant mortality in Malang. As the data that researchers have collected from various sources, the following are:

Graph 2. Number of AKI and AKB Cases in Malang District in 2016-2020

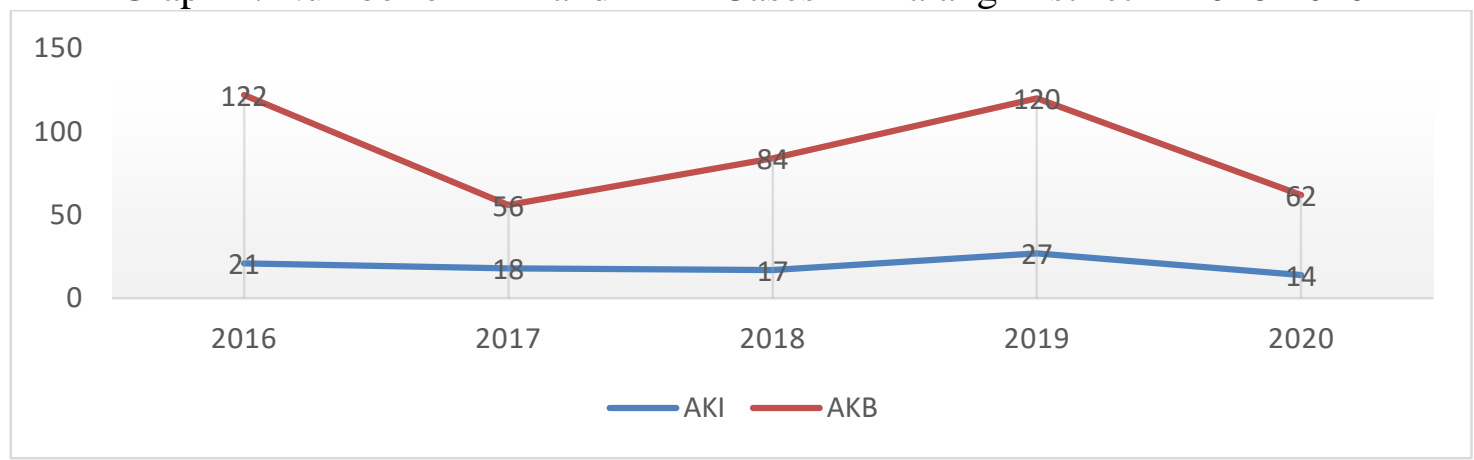

Source: Processed from a variety of sources

In 2020 the number of maternal and infant deaths fell compared to 2019. However, this sustainability does not work consistently due to the capacity of institutional innovation. 
Innovations within a public organisational structure usually impact management and organisational patterns. According to Walker (2014:23), innovation changes relationships between members of the organisation, affecting rules, roles, procedures, and communication with each other. Local governments play a role in doing careful planning, creating, and interpreting in a government innovation system (Ma et al., 2019:47). This means that Contra War innovation has changed the pattern of relationships and communication that exist in $\mathrm{kb}$ management, especially at the time of surveillance. As in Changzhou, China, Ma et al. (2019:29) explains that local governments play an important role in creating an innovation ecosystem, starting with the government bureaucracy system.

In general, Contra War innovation has a basic concept of One RW-One Cadre; One acceptor/woman of new childbearing age is at high risk accompanied by a trained KB cadre and selected contraceptive for the selected woman. All three are assisted by information technology through android-based servers and reporting. It reinforces what the majority of scholar says that the existence of information technology can help public organisations' work in solving social problems (Kuziemski \&Misuraca, 2020:1). With an information technologybased approach, the evaluation was also conducted in real-time through the website. The existence of this website also encourages transparency of handling by local governments and efforts to disseminate information on handling decreased Maternal Mortality (AKI) and Infant Mortality Rate (AKB).

However, due to the lack of maintenance and the commitment of the implementer, the sustainability of the website did not go well. Whereas with an IT-based approach, policymakers can take evidence-based problem-solving innovations (evidence-based innovation). Next, if we look at the website above also shows that the Contraceptive for Woman at Risk Website has not experienced upgrading database since 2018, so the sustainability of contra war innovation is questionable because, in the local context, community participation is also very important to produce quality and sustainable public services (Biljohn \&Lues, 2020:230; Haikio, 2012:418). Although this innovation uses three approaches (see table 4), updating data also largely depends on the participation of the public and the cadres of surveillance.

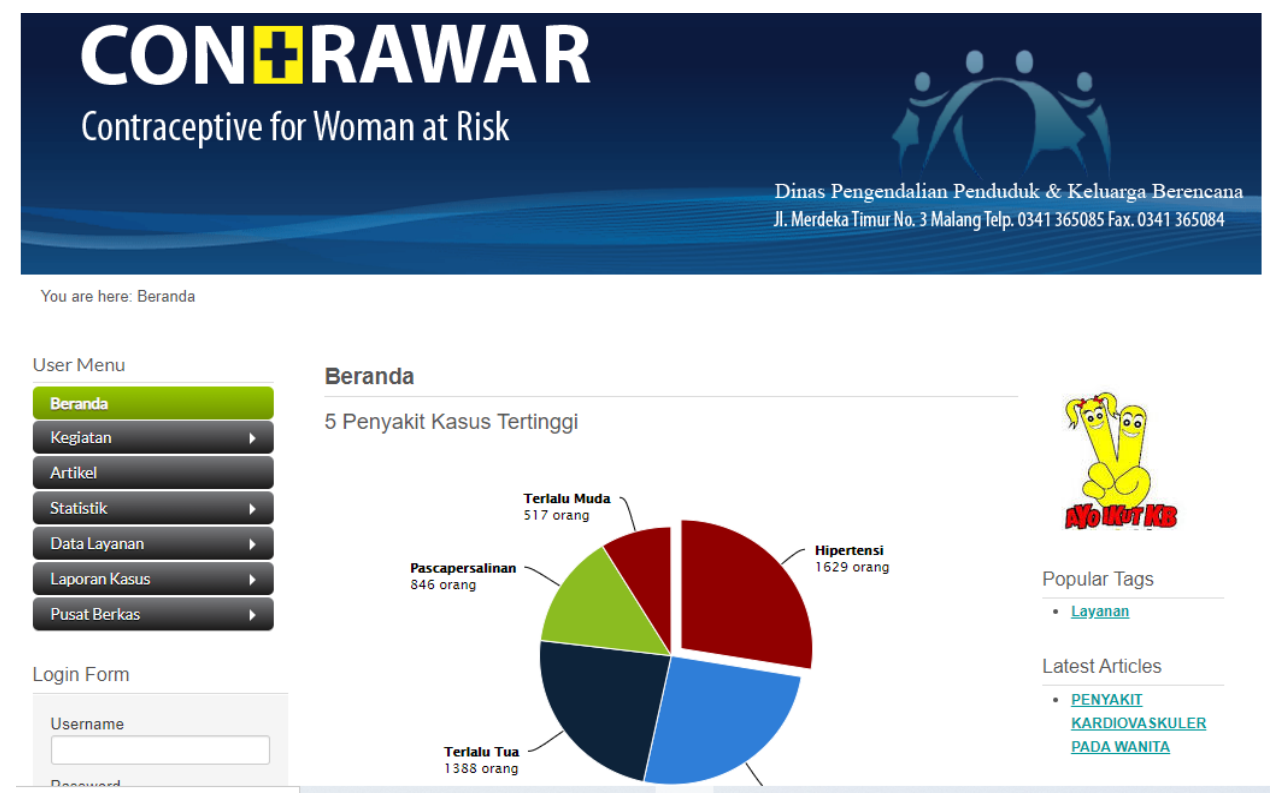

Figure 4. Contra War Website Display

One thing to remember is that public sector innovation not only has a positive impact but also has a "dark side". This means that innovations that bring new and exciting ideas are 
often applied on a small scale but do not result in widespread change (Meijer \&Thaens, 2021:139). Although theoretically commitment and adherence to performance as well as results-oriented systems and might integrated administrative politics, it looks easy. However, in practice, many public organisations are not able to apply perfectly. An example is the government of Malang Regency, with its contra war innovation that is unsustainable and has not been able to bring about institutionalised public innovation due to lack of stability as described by Meijer \&Thaens (2021:140).

Innovative governance focused on the function of government can have a positive impact on the increase of public trust (Andhika et al., 2018b:90). Moreover, the public service innovation award given by the Ministry of Administrative And Bureaucratic Reform, many encourage public organisations to innovate, replicate and adopt, including Contra War innovation in Malang Regency, which is included in the top 40 public service innovations in 2018 because it is considered to be beneficial for the decrease in Maternal and Infant Mortality (AKI-AKB). However, as with most public sector innovation patterns in Indonesia, many innovations in the region only grow due to the role of its leader transformative leadership in driving the entire apparatus and creating an innovative ecosystem (Khan \& Khan (2019:5).

Meijer \& Thaens (2021:143) explained that innovation in the public sector is often dominated by technocratic decisions, thus affecting the slow process of operationalisation and institutional innovation. At a glance, the concept presented by Hjelmar (2019:5-6) contains two great approaches: (1) Form and how to operationalise innovation programs; (2) How much innovation institutionalises and becomes a broad culture.

So we can simplify that Contra War Innovation in Malang Regency from the perspective of Public Sector Innovation has not been able to produce an innovative and internally cultured framework, as well as consistency and effectiveness of program sustainability to reduce maternal and infant mortality (AKI-AKB).

The sustainability of Contra War innovation is largely due to the leading factor, also due to the lack of private involvement in the innovation process. Innovation requires a private role, such as the study conducted by Bakici et al. (2013:311) in the case of local government innovation in Filandia, Germany, the Netherlands, and Spain. Private roles can help to discuss the forms of innovation, proposals, and technologies that support innovation programs. This is what we have not found in the case of Contra War innovation in Malang Regency, which is handled entirely by the Office of Population Control and Family Planning Malang and other relevant OPD.

\section{E. CONCLUSION}

Public sector innovation, Contra War in Malang regency aims to solve social problems, namely lowering maternal and infant mortality. This innovation is based on real-time data with command centre monitoring technology and an evidence-based innovation process. As a local innovation, Contra War innovation involves many stakeholders in its implementation, including the Regent of Malang as a supervisor and coach, the Regional Secretary as the person in charge, the Administrative Assistant of government, and the Legal Department, as an institution for the preparation of legal products. Dinkes, RSUD, KP3A as SKPD technical implementation partner of Contra War innovation, DPPKB especially Kb Cadres as the spearhead of innovation. Contra War innovation also uses three main approaches, namely organising, participation, information technology.

Despite being awarded the top 40 public service innovations in 2018, overall, this innovation has not been able to have a significant impact on the problem of maternal and infant mortality. During this time, innovation has always been considered to have a positive 
impact, but forget about some of the "dark side" of public sector innovation such as administrative prerequisites, leadership, innovation instability, and technocratic nature. It is impacting the internal and external conditions of a public sector innovation.

The sustainability of Contra War innovation is not good because it is influenced by community participation and health capacity owned by Malang Regency. In addition to the low capacity of innovation in the organisation and the lack of transformational leadership in the region. Therefore, to ensure the sustainability and success of contra war innovation, it is necessary to enhance more intensive cooperation with the private sector as an effort by public organisations to create innovative ecosystems and frameworks. To increase community participation and private role in supporting innovation in local government. Further research related to public sector innovation can be done with more focus on how public organisations efforts in creating innovative ecosystems and frameworks. Also, how to increase public participation and private role in supporting innovation in public organisations.

\section{Acknowledgements}

The authors would like to thanks for Faculty of Social and Political Sciences, Universitas Muhammadiyah Malang has funded this research [E.6.k/154/FISIP/UMM/II/2020]. Also, this article is dedicated as a gift to my son (first author), Wafi Alhanan, who was born at the end on May 2021.

\section{REFERENCES}

Ammons, D. N., Smith, K. W., \& Stenberg, C. W. (2012). The Future of Local Government: Will Current Stresses Bring Major, Permanent Changes?. State and Local Government Review, 44(1_suppl), 64S-75S. https://doi.org/10.1177/0160323x12454143

Andhika, L. R. (2018a). Bureaucracy Innovation: Hybrid Theory Perspective. Jurnal Borneo Administrator, 14(2), 151-170. https://doi.org/10.24258/jba.v14i2.349

Andhika, L. R. (2018b). Discretion and Decentralisation: Public Administrators Dilemmas in Bureaucracy Innovation Initiatives. Otoritas : Jurnal Ilmu Pemerintahan, 8(1), 17-31. https://doi.org/10.26618/ojip.v8i1.1040

Anggraeny, C. (2013). Inovasi Pelayanan Kesehatan dalam Meningkatkan Kualitas Pelayanan di Puskesmas Jagir Kota Surabaya. Jurnal Kebijakan Dan Manajemen Publik, 1(1), 85-93.

Arundel, A., Bloch, C., \& Ferguson, B. (2019). Advancing innovation in the public sector: Aligning innovation measurement with policy goals. Research Policy, 48(3), 789-798. https://doi.org/10.1016/j.respol.2018.12.001

Bakici, T., Almirall, E., \& Wareham, J. (2013). The role of public open innovation intermediaries in local government and the public sector. Technology Analysis and Strategic Management, 25(3), 311-327. https://doi.org/10.1080/09537325.2013.764983

Bekkers, V., \& Tummers, L. (2018). Innovation in the public sector: Towards an open and collaborative approach. International Review of Administrative Sciences. https://doi.org/10.1177/0020852318761797

Bernier, L., Hafsi, T., \& Deschamps, C. (2015). Environmental Determinants of Public Sector Innovation: A study of innovation awards in Canada. Public Management Review, 17(6), 834-856. https://doi.org/10.1080/14719037.2013.867066

Biljohn, M. I. M., \& Lues, L. (2020). Citizen Participation, Social Innovation, and the Governance of Local Government Service Delivery: Findings from South Africa. International Journal of Public Administration, 43(3), 229-241. https://doi.org/10.1080/01900692.2019.1628052

Boehmke, F. J., \& Witmer, R. (2004). Disentangling Diffusion: The Effects of Social Learning and Economic Competition on State Policy Innovation and Expansion. 

Political
Research
Quarterly,
$57(1)$
$39-51$.

https://doi.org/10.1177/106591290405700104

Borins, S. (2014). The Persistence of Innovation in Government: A Guide for Innovative Public Servants. Innovation Series - the IBM Center for The Business of Government, 44. https://doi.org/10.1080/19440040903296840

Borins, S. (2018). Public sector innovation in a context of radical populism. Public Management Review, 20(12), 1858-1871. https://doi.org/10.1080/14719037.2018.1441430

BPS Kabupaten Malang. (2020). Kabupaten Malang Dalam Angka 2020. Malang.

BPS Provinsi Jawa Timur. (2019). Jumlah Pasangan Usia Subur dan Peserta KB Aktif di Provinsi JawaTimur Menurut Kabupaten/Kota, 2018.

Cinar, E., Trott, P., \& Simms, C. (2019). A systematic review of barriers to public sector innovation process. Public Management Review, 21(2), 264-290. https://doi.org/10.1080/14719037.2018.1473477

Conrad, P. (2001). Health Research, Qualitative. International Encyclopedia of the Social \& Behavioral Sciences, 6608-6612. https://doi.org/https://doi.org/10.1016/B0-08-0430767/03904-8

De Vries, H., Bekkers, V., \& Tummers, L. (2016). Innovation in the public sector: A systematic review and future research agenda. Public Administration, 94(1), 146-166. https://doi.org/10.1111/padm.12209

Demircioglu, M. A. (2019). Why does innovation in government occur and persist? Evidence from the Australian government. Asia Pacific Journal of Public Administration, 41(4), 217-229. https://doi.org/10.1080/23276665.2019.1692570

Demircioglu, M. A., \& Audretsch, D. B. (2017). Conditions for innovation in public sector organisations. Research Policy, 46(9), 1681-1691. https://doi.org/10.1016/j.respol.2017.08.004

Demircioglu, M. A., \& Audretsch, D. B. (2018). Conditions for complex innovations: evidence from public organisations. Journal of Technology Transfer, 45(3), 820-843. https://doi.org/10.1007/s10961-018-9701-5

Diercks, G., Larsen, H., \& Steward, F. (2019). Transformative innovation policy: Addressing variety in an emerging policy paradigm. Research Policy, 48(4), 880-894. https://doi.org/10.1016/j.respol.2018.10.028

Dinas Pengendalian Penduduk dan Keluarga Bencana. (2018). Proposal Inovasi Percepatan Penurunan Angka Kematian Ibu (AKI) dan Angka Kematian Bayi (AKB) Melalui Program Contra War (Contraceptive Women at Risk) di Kabupaten Malang. Malang.

Dinas Pengendalian Penduduk dan Keluarga Berencana. (2019). Laporan Kinerja Tahun 2019. Kab. Malang.

Dorsman, S. J., Tummers, L. G., \& Thaens, M. (2014). Understanding public sector innovations: The role of leadership activities for a climate for innovation. ResearchGate, $31(0)$.

Eprilianto, D. F., Pradana, G. W., \& Sari, Y. E. K. (2019). Digital Inovasi Sektor Publik: Efektivitas Kolaborasi Dalam Implementasi Inovasi Dega Digital. Jurnal EL-RIYASAH, 10(2), 127. https://doi.org/10.24014/jel.v10i2.8909

Febrian, R. A. (2018). Inovasi Daerah dari Perspektif Regulasi, Konseptual, dan Empiris (Tinjauan terhadap pasal Pasal 386 Undang-Undang Nomor 23 Tahun 2014 tentang Pemerintahan Daerah) Oleh. Jurnal Kajian Pemerintah, IV(1), 44-55. https://doi.org/https://doi.org/10.25299/jkp.2018.vol4(1).2168

Goodman, V. D. (2011). A brief overview of qualitative research. Qualitative Research and the Modern Library, 7-31. https://doi.org/10.1016/b978-1-84334-644-9.50001-9 
Goodsell, C. T. (2017). Publicness. Administration and Society, 49(4), 471-490. https://doi.org/10.1177/0095399716656224

Grillitsch, M., Hansen, T., Coenen, L., Miörner, J., \& Moodysson, J. (2019). Innovation policy for system-wide transformation: The case of strategic innovation programs (SIPs) in Sweden. Research Policy, 48(4), 1048-1061. https://doi.org/10.1016/j.respol.2018.10.004

Häikiö, L. (2012). From Innovation to Convention: Legitimate Citizen Participation in Local Governance. Local Government Studies, 38(4), 415-435. https://doi.org/10.1080/03003930.2012.698241

Hartley, J. (2005). Innovation in governance and public services: Past and present. Public Money and Management, 25(1), 27-34. https://doi.org/10.1111/j.14679302.2005.00447.x

Hartley, J., \& Rashman, L. (2018). Innovation and inter-organisational learning in the context of public service reform. International Review of Administrative Sciences, 84(2), 231248. https://doi.org/10.1177/0020852318762309

Hjelmar, U. (2019). The institutionalisation of public sector innovation. Public Management Review, OO(00), 1-17. https://doi.org/10.1080/14719037.2019.1665702

Janssen, M., Konopnicki, D., Snowdon, J. L., \& Ojo, A. (2017). Driving public sector innovation using big and open linked data (BOLD). Information Systems Frontiers, 19(2), 189-195. https://doi.org/10.1007/s10796-017-9746-2

Kayesa, N. K., \& Shung-King, M. (2021). The role of document analysis in health policy analysis studies in low and middle-income countries: Lessons for HPA researchers from a qualitative systematic review. Health Policy OPEN, 2(November 2019), 100024. https://doi.org/10.1016/j.hpopen.2020.100024

Khan, N. A., \& Khan, A. N. (2019). What followers are saying about transformational leaders fostering employee innovation via organisational learning, knowledge sharing and social media use in public organisations? Government Information Quarterly, 36(4), 101391. https://doi.org/10.1016/j.giq.2019.07.003

Kusumasari, B., Pramusinto, A., Santoso, A. D., \& Fathin, C. A. (2019). What shapes public sector innovation? Public Policy and Administration, 18(4), 430-446. https://doi.org/10.13165/VPA-19-18-4-05

Kuziemski, M., \& Misuraca, G. (2020). AI governance in the public sector: Three tales from the frontiers of automated decision-making in democratic settings. Telecommunications Policy, 44(6), 101976. https://doi.org/10.1016/j.telpol.2020.101976

Lapuente, V., \& Suzuki, K. (2020). The prudent entrepreneurs: women and public sector innovation. Journal of European Public Policy, O(0), 1-27. https://doi.org/10.1080/13501763.2020.1770316

Ma, L., Liu, Z., Huang, X., \& Li, T. (2019). The Impact of Local Government Policy on Innovation Ecosystem in Knowledge Resource Scarce Region: Case Study of Changzhou, China. Science, Technology and Society, 24(1), 29-52. https://doi.org/10.1177/0971721818806096

Malang, P. K. (2018). Laporan Akhir Penyusunan Indeks Pembangunan Manusia (IPM) Kabupaten Malang Tahun Anggaran 2018. Malang.

Maranto, R., \& Wolf, P. J. (2013). Cops, Teachers, and the Art of the Impossible: Explaining the Lack of Diffusion of Innovations That Make Impossible Jobs Possible. Public Administration Review, 73(2), 230-240. https://doi.org/10.1111/j.15406210.2012.02626.x

McGann, M., Blomkamp, E., \& Lewis, J. M. (2018). The rise of public sector innovation labs: experiments in design thinking for policy. Policy Sciences, 51(3), 249-267. https://doi.org/10.1007/s11077-018-9315-7 
Meijer, A., \& Thaens, M. (2021). The Dark Side of Public Innovation. Public Performance \& Management Review, 44(1), 136-154. https://doi.org/10.1080/15309576.2020.1782954

Mubin, F., \& Roziqin, A. (2018). Meritocracy of Bureaucracy in Indonesia. International Journal of Social Science and Humanity, 8(8), 241-246. https://doi.org/10.18178/ijssh.2018.v8.968

Muhammad, I. (2020). Dinkes Kabupaten Malang: Angka Kematian Bayi dan Ibu Terus Menurun. Retrieved Februari 21, 2020, from https://www.timesindonesia.co.id/ website: https://www.timesindonesia.co.id/read/news/202636/dinkes-kabupaten-malang-angkakematian-bayi-danibu-terus-menurun

Murtadho, I., \& Roziqin, A. (2018). 26. Public Governance Perspective To Adressing Development Problems in Surabaya City. 241(IcoSaPS), 109-114. https://doi.org/10.2991/icosaps-18.2018.26

Nählinder, J. (2013). Understanding innovation in a municipal context: A conceptual discussion. Innovation: Management, Policy and Practice, 15(3), 315-325. https://doi.org/10.5172/impp.2013.15.3.315

Niskanen, W. A. (2012). Gordon Tullock's contribution to bureaucracy. Public Choice, 152(1/2), 97-101. https://doi.org/10.1007/s11127-011-9851-6

OECD. (2015). The Innovation Imperative Contributing to Productivity, Growth and Wellbeing. Organization for Economic Co-operation and Development. Paris.

Osborne, S. P. (2009). Debate: Delivering public services: Are we asking the right questions? Public Money and Management, 29(1), 5-7. https://doi.org/10.1080/09540960802617269

Pratama, A. B. (2019). The landscape of public service innovation in Indonesia. Innovation \& Management Review, 17(1), 25-40. https://doi.org/10.1108/inmr-11-2018-0080

Putra, A., Usman, J., \& Abdi. (2017). Inovasi Pelayanan Publik Bidang Kesehatan Berbasis Home Care di Kota Makassar. Jurnal Administrasi Publik, 3(3).

Rene, M., Kismartini, \& Purnaweni, H. (2019). Konteks Lembaga Dalam Implementasi Kebijakan Pengurangan Kematian Bayi di Kabupaten Kupang. Jurnal Borneo Administrator, 15(3), 333-352. https://doi.org/https://doi.org/10.24258/jba.v15i3.499

Rozikin, M., Hesty, W., \& Sulikah. (2020). Kolaborasi Dan E-Literacy: Kunci Keberhasilan Inovasi E-Government Pemerinah Daerah. Jurnal Borneo Administrator, 16(1), 61-80. https://doi.org/10.24258/jba.v16i1.603

Sigit. (2020). Tekan Angka Kematian Ibu dan Bayi, Butuh Peningkatan Keahlian Bidan. Retrieved September 11, 2020, from https://www.mitratoday.com/ website: https://www.mitratoday.com/tekan-angka-kematian-ibu-dan-bayi-butuh-peningkatankeahlian-bidan/

Sinni, G. (2017). Participatory Design for Public Services. Innovation in Public Administration. The Design Journal, 20(sup1), S3368-S3379. https://doi.org/10.1080/14606925.2017.1352841

Sururi, A. (2017). Inovasi Kebijakan Publik (Tinjauan Konseptual Dan Empiris). (September 2016).

Susiana, S. (2019). Angka Kematian Ibu: Faktor Penyebab Dan Upaya Penanganannya. Pusat Penelitian Badan Keahlian DPR RI, XI(24), 13-18.

Torfing, J., \& Ansell, C. (2017). Strengthening political leadership and policy innovation through the expansion of collaborative forms of governance. Public Management Review. https://doi.org/10.1080/14719037.2016.1200662

van der Wal, Z., \& Demircioglu, M. A. (2020). Public sector innovation in the Asia-pacific trends, challenges, and opportunities. Australian Journal of Public Administration, 79(3), 271-278. https://doi.org/10.1111/1467-8500.12435 
Velsberg, O., Westergren, U. H., \& Jonsson, K. (2020). Exploring smartness in public sector innovation - creating smart public services with the Internet of Things. European Journal of Information Systems, 00(00), 1-19. https://doi.org/10.1080/0960085X.2020.1761272

Walker, R. M. (2014). Internal and External Antecedents of Process Innovation: A review and extension. Public Management Review, 16(1), 21-44. https://doi.org/10.1080/14719037.2013.771698 